\title{
EVALUATION OF SMALL INTESTINE BACTERIAL OVERGROWTH IN PATIENTS WITH FUNCTIONAL DYSPEPSIA THROUGH $\mathrm{H}_{2}$ BREATH TEST
}

\author{
Michelle Bafutto Gomes COSTA ${ }^{1}$, Itaciron Luz AZEREDO Jr. ${ }^{1}$, \\ Ricardo Duarte MARCIANO'1, Luciana Morelli CALDEIRA' 1 and Mauro BAFUTTO²
}

\begin{abstract}
Context - Functional dyspepsia is a condition in which symptoms are not related to organic underlying disease; its pathogenesis is not well known. The small intestinal bacterial overgrowth (SIBO) is characterized by the increase in the number and/or type of colonic bacteria in the upper gastrointestinal tract. The hypothesis of SIBO being associated to functional dyspepsia must be considered, since the impaired motility of the gastrointestinal tract is one of the main etiologic factors involved on both pathologies. Objective - To determine if there is SIBO in patients with functional dyspepsia. Methods - Case-control study, evaluating 34 patients: 23 functional dyspeptic and 11 non-dyspeptic (control group). Questionnaire applied based on Rome III criteria. The patients underwent $\mathrm{H}_{2}$-lactulose breath test, considered positive when: $\mathrm{H}_{2}$ peak exceeding $20 \mathrm{ppm}$, in relation to fasting, or two peaks exceeding 10 ppm sustained until 60 minutes. Results - Of the 23 dyspeptic patients, 13 (56.5\%) obtained positive results for SIBO trough the $\mathrm{H}_{2}$-lactulose breath test. On control group, SIBO was not observed. The association between the dyspeptic group and the control group regarding SIBO was statistically significant, with $P=0.0052$. In the group of dyspeptic patients, $12(52.2 \%)$ were using proton pump inhibitor; of these $9(75 \%)$ were positive for SIBO. In the control group, none of the 11 patients used proton pump inhibitors and SIBO was not observed. The association of the dyspeptic group using proton pump inhibitor that were positive for SIBO and the control group was statistically significant, with $P=0.0011$. Conclusion - It was found that, patients with functional dyspepsia presented SIBO, when they underwent to H2-lactulose breath test, compared to the non-dyspeptic. In addition, it was observed a higher prevalence of SIBO in dyspeptic patients that were using proton pump inhibitors, compared to control group.
\end{abstract}

HEADINGS - Bacterial growth. Intestine, small. Dyspepsia. Hydrogen. Proton pump inhibitors.

\section{INTRODUCTION}

Functional dyspepsia is characterized by a set of chronic and recurrent symptoms that are usually located in the epigastric region, in the absence of structural or metabolic and biochemical abnormalities that justify the symptomatology $y^{(9,13,20)}$. Dyspeptic symptoms may appear at any age and are more prevalent in females ${ }^{(8)}$.

The most frequent cause of dyspepsia is functional dyspepsia. Although a benign condition, its pathogenesis is not well defined ${ }^{(20)}$. It is the most common reason for medical consultations, both for general and specialists, and it may affect up to $25 \%$ of population $^{(7)}$. Its most severe forms have great impact on patients quality of life $\mathrm{e}^{(3,24)}$.

In 2006, Rome III consensus criteria defined functional dyspepsia as the presence of at least one of the symptoms originating from the gastroduodenal region: epigastric pain, epigastric burning, postprandial fullness and early satiety, without evidence of structural changes justifying the symptoms. These symptoms must be present in the last 3 months and its start at least 6 months before diagnosis. There should be no evidence that symptoms improve or are associated with changes of intestinal rhythm or on evacuation characteristics ${ }^{(5,16)}$

The pathogenesis of functional dyspepsia symptoms is not completely clarified, having as possible etiological mechanisms: gastroduodenal motor disorders, changes in visceral sensitivity and the involvement of emotional disturbances in the modulation of motor and sensory functions ${ }^{(2,10,23)}$.

Small intestine bacterial overgrowth (SIBO) is characterized by the increase in number and/or type of colonic bacteria in the upper gastrointestinal tract. It is defined as the finding of more than $10^{5}$ Colony Forming Units (CFU/mL) in the upper small intestine

\footnotetext{
Declared conflict of interest of all authors: none.

${ }_{1}^{1}$ Departamento de Medicina, Pontifícia Universidade Católica de Goiás: ${ }^{2}$ Instituto Goiano de Gastroenterologia e Endoscopia Digestiva, Goiânia, GO, Brasil.

Correspondence: Dr. Mauro Bafutto - Rua 246, 25 - Setor Coimbra - 74535-170 - Goiânia, GO. Brazil. E-mail: maurobafutto@yahoo.com.br
} 
or $10^{3} \mathrm{CFU} / \mathrm{mL}$ if isolated bacteria are typical from large intestine $^{(4,19)}$.

Affected patients may be asymptomatic or have symptoms such as: fullness, abdominal discomfort, diarrhea, steatorrhea, flatulence, dyspepsia, malabsorption of nutrients, weight loss or no weigh gain ${ }^{(21,25,26)}$.

The gold standard for diagnosis of SIBO is the jejunal aspirate, but it has several limitations ${ }^{(6,25)}$. $\mathrm{H}_{2}$ breath test, using glucose or lactulose, is a non-invasive, low cost, simple and safe alternative with good sensibility and specificity ${ }^{(15,19)}$.

After analysis on the latest studies of SIBO, it may be observed that the change in gastric acidity and gastroduodenal motility are its main causes ${ }^{(5,4,25)}$.

The hypothesis that SIBO is associated with functional dyspepsia should be considered, once the motility disorder is one of the main etiologic factors involved in both entities.

From these available data and considering the importance of functional dyspepsia in the medical context today, we built this investigation study for the presence of SIBO in functional dyspeptic patients, by using the hydrogen breath test.

\section{METHOD}

This is a case-control study conducted at Instituto Goiano de Gastroenterologia e Endoscopia Digestiva (IGGED), Goiânia, GO, Brazil, from July 2011 to February 2012. This study was previously submitted and approved by the Ethics Committee of Pontifícia Universidade Católica de Goiás. We evaluated 34 patients between ages 18 and 65, with normal upper endoscopy and upper abdominal ultrasonography, being 23 patients ( 6 men and 17 women) with one ore more dyspeptic symptoms (postprandial fullness, epigastric burning, early satiety and epigastric pain) compared with 11 patients (6 men and 5 women) without dyspeptic symptoms (control group). Patients accepted to participate in the study after signing the free and informed consent term. Patients excluded this study were: individuals under the age of 18 years or over 65 , pregnant women, patients with chronic obstructive pulmonary disease, smokers, patients with gastroesophageal reflux disease, irritable bowel syndrome or any other organic disease involving gastrointestinal tract, and patients that did not agree to participate on the study or did not sign the free and informed consent term.

A questionnaire on dyspeptic symptoms was applied. It was developed by the researchers, based on Rome III criteria (2006). Patients with symptoms in the last 3 months and its start at least the last 6 months and not associated with symptoms that could meet irritable bowel syndrome criteria were considered as having functional dyspepsia.

Patients were tested using $\mathrm{H}_{2}$ breath test. A basal sample of exhaled air was collected corresponding to the 8 hours fasting sample. After ingestion of $15 \mathrm{~mL}$ of lactulose $667 \mathrm{mg} / \mathrm{mL}$ (EMS Sigma Pharma Ltd), exhaled air samples were collected at the following times: $15,30,45,60,75,90,105$ e 120 minutes. The result was considered positive for SIBO when the peak of $\mathrm{H}_{2}$ was greater than 20 parts per million $(\mathrm{ppm})$ in relation to fasting, or two peaks greater than 10 ppm sustained until 60 minutes after ingestion of lactulose ${ }^{(1)}$

For collection of exhaled air, the device "AlveoSampler" (Quintron Instrument Co. Inc., Milwaukee, WI, USA) was used. It consists of an intermediate containing a small whole for insertion of an air flow stopcock attached to a $35 \mathrm{~mL}$ syringe, from where air is withdrawn to be analyzed. At the inlet end, a nozzle adapted to the intermediate was perfectly coupled to the patient's mouth, meanwhile the other end of the intermediate contained a polyethylene bag. After this bag was filled, $20 \mathrm{~mL}$ of alveolar air were withdrawn by syringe and immediately analyzed in a BreathTracker $\mathrm{H}_{2}$ gas chromatographer (Quintron Instrument Co. Inc., Milwaukee, WI, USA) which quantifies the exhaled hydrogen in ppm.

Data obtained were analyzed by Epi Info, version 3.5.1, in order to study the association between the variables (SIBO and functional dyspepsia), for which we used the Yates corrected chi-square test with significance level of $5 \%(P<0.05)$.

\section{RESULTS}

Of the 34 patients analyzed, $22(64.7 \%)$ were females and $12(35.3 \%)$ were males. Age ranged from 18 to 65 years with an average of $38.8 \pm 12.62$. The group of patients with dyspepsia was composed by 23 patients, being $6(26 \%)$ males and $17(74 \%)$ females. The control group was composed by 11 patients, being $6(54.5 \%)$ males and $5(45.5 \%)$ females (Table 1).

TABLE 1. Number of patients according to gender in each group

\begin{tabular}{lcc}
\hline & Female & Male \\
\hline Dyspeptic & 17 & 6 \\
Control & 5 & 6 \\
Total & 22 & 12 \\
\hline
\end{tabular}

Of all dyspeptic patients, $13(56.5 \%)$ tested positive for SIBO through $\mathrm{H}_{2}$ breath test (Figure 1). Of these, $10(76.9 \%)$

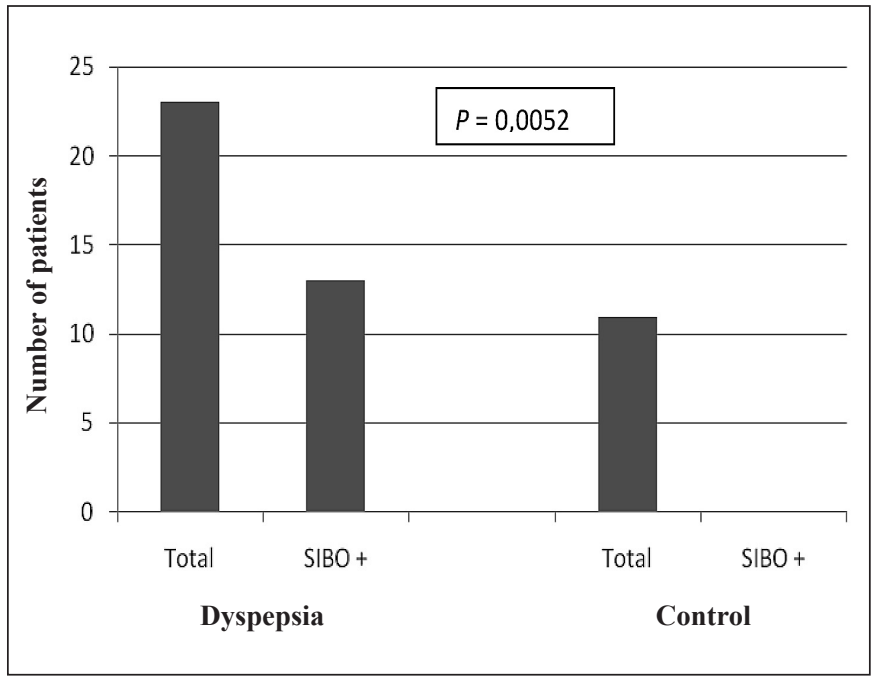

FIGURE 1. Presence of SIBO in dyspeptic patients and control group 
were women and $3(23.1 \%)$ were men (Figure 2). On the control group, SIBO was not shown through $\mathrm{H}_{2}$ breath test. The association between the dyspeptic group and the control group in relation to SIBO showed a $P$ value of 0.0052 .

Dyspeptic patients were classified according to the dyspepsia presented: $4(18 \%)$ patients with predominance of pain, $10(43 \%)$ with fullness and $9(39 \%)$ mixed (Figure 3).

Of $4(18 \%)$ patients with dyspepsia type pain, $3(75 \%)$ were tested positive for SIBO through $\mathrm{H}_{2}$ breath test. Of

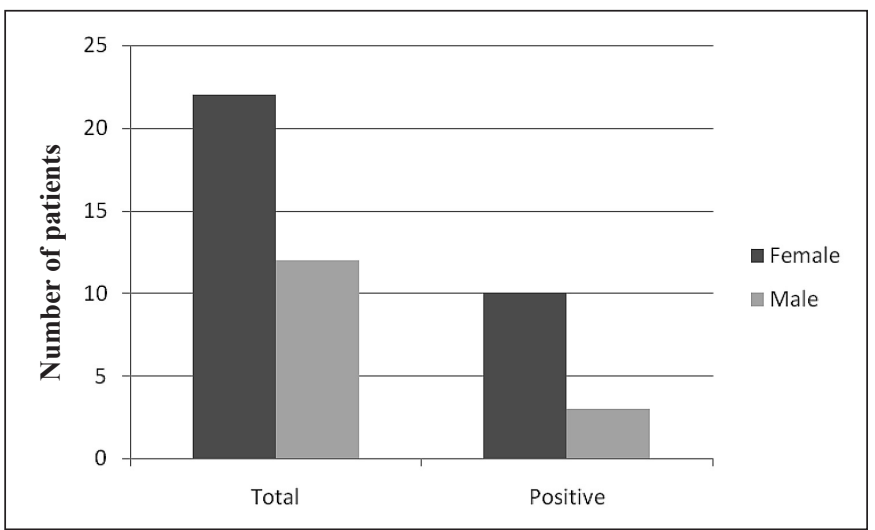

FIGURE 2. Positivity for SIBO using the $\mathrm{H}_{2}$ breath test, by gender

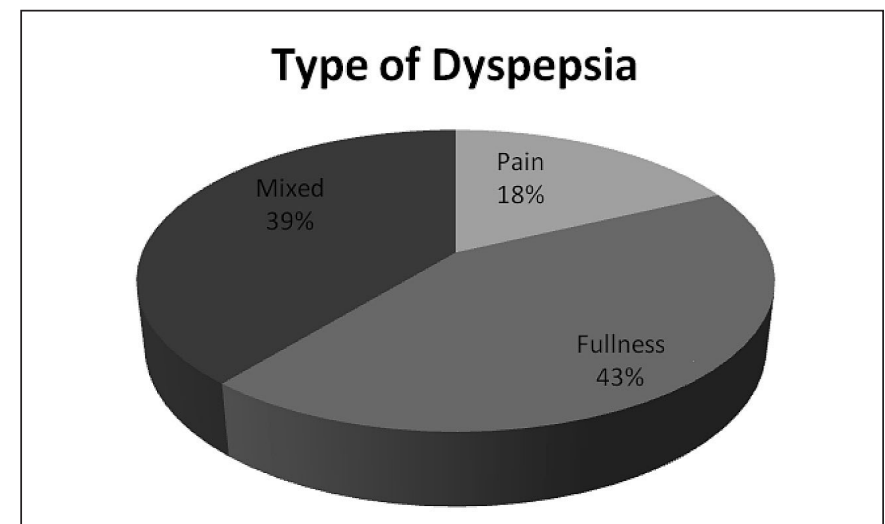

FIGURE 3. Percentage of the dyspepsia type in relation to the total of dyspeptic patients

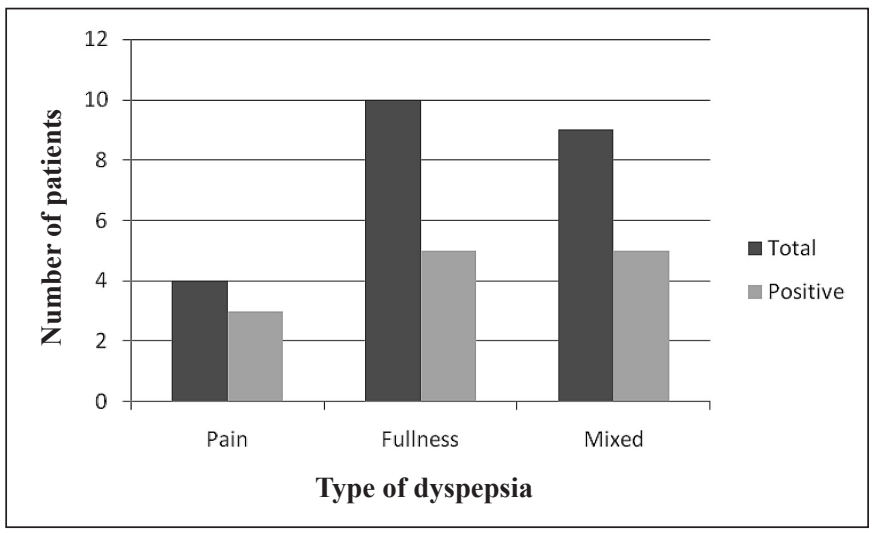

FIGURE 4. Number of dyspeptic patients with positive result for SIBO in relation to the dyspepsia type
$10(43 \%)$ patients with dyspepsia type fullness $5(50 \%)$ were tested positive for SIBO. Of $9(39 \%)$ patients with dyspepsia type mixed, $5(55.5 \%)$ were positive for SIBO (Figure 4 )

In the group of dyspeptic patients, $12(52.2 \%)$ were using proton pump inhibitor (PPI); of these $9(75 \%)$ were positive for SIBO. In the same group, $11(47.8 \%)$ patients did not use PPI and of these, $5(45.4 \%)$ were positive for SIBO. The association between the use of PPIs in dyspeptic patients and its lack of usage in the same group with SIBO was not statistically significant $(P=0.3065)$ (Table 2$)$.

TABLE 2. Dyspepsia with and without use of PPI, regarding SIBO

\begin{tabular}{lccc}
\hline & SIBO + & SIBO- & $P$ value* \\
\hline Dyspepsia with PPI & 9 & 3 & 0.3065 \\
Dyspepsia without PPI & 5 & 6 & \\
Total & 14 & 9 & \\
\hline
\end{tabular}

*chi-square test

In the control group, none of the 11 patients used PPIs and SIBO was not observed.

The association of the dyspeptic group using PPI (12 patients) that were positive for SIBO and the control group was statistically significant, with $P=0.0011$ (Table 3).

TABLE 3. Dyspepsia with PPI and control group, in relation to SIBO

\begin{tabular}{lccc}
\hline & SIBO + & SIBO- & $P$ value* \\
\hline Dyspepsia with PPI & 9 & 3 & 0.0011 \\
Control group & 0 & 11 & \\
Total & 9 & 14 & \\
\hline
\end{tabular}

*chi-square test

The association of the dyspeptic group without any use of PPI (11) that were positive for SIBO and the control group (11) was statistically significant, with $P=0.0419$ (Table 4).

TABLE 4. Dyspepsia without PPI and control group, in relation to SIBO

\begin{tabular}{lccc}
\hline & SIBO+ & SIBO- & $\boldsymbol{P}$ value* \\
\hline Dyspepsia without PPI & 5 & 6 & 0.0419 \\
Control group & 0 & 11 & \\
Total & 5 & 17 & \\
\hline
\end{tabular}

*hi-square test

\section{DISCUSSION}

This study evaluated the occurrence of intestinal bacterial overgrowth in patients with dyspeptic symptoms, with functional dyspepsia diagnosis, using the $\mathrm{H}_{2}$ breath after ingestion of lactulose. In the present study, $13(56.5 \%)$ of the 23 dyspeptic patients analyzed, showed abnormalities in the breath test, thus being considered as having intestinal bacterial overgrowth, contrasting with the control group in which there was no evidence of this occurrence. The difference in frequency of SIBO was statistically significant.

This is a pioneering study, there are no publications in 
comparing such variables so far. However, studies in this direction are being made ${ }^{(11)}$.

Of the dyspeptic patients that were positive for SIBO on $\mathrm{H}_{2}$ breath test, $10(76.9 \%)$ were females and $3(23.1 \%)$ were males, confirming the literature data, when dyspepsia in relation to gender is studied ${ }^{(18)}$. On the control group, SIBO was not observed in the $\mathrm{H}_{2}$ breath test.

All patients were tested using $\mathrm{H}_{2}$ breath test with $15 \mathrm{~mL}$ of lactulose as substrate. This substrate is not absorbed in the small intestine, but it is metabolized by the colonic flora. Therefore, every exam shows the $\mathrm{H}_{2}$ peak lift approximately 90 minutes after ingestion of lactulose, corresponding to its arrival at the colon and representing the orocecal transit time ${ }^{(24)}$. The breath test is based on the quantification of the concentration of $\mathrm{H}_{2}$ in the expired air, which is produced from intestinal bacterial metabolism ${ }^{(14)}$. It is a simple, safe, non-invasive diagnosis method for SIBO, with $44 \%$ specificity and $68 \%$ sensibility ${ }^{(17)}$. Its interpretation can be compromised when there are diseases associated with delayed gastric emptying (false negative) or rapid intestinal transit (false positive) $^{(1)}$.

The colonization of the upper gastrointestinal tract by species characteristic of the colon was usually associated to structural abnormalities of the small intestine ${ }^{(24)}$. However, recent studies have shown that SIBO may present as mild and unspecific symptoms in patients without structural alteration of this organ ${ }^{(1)}$, such as functional dyspepsia patients.

In this study of the patients with dyspepsia type pain, three $(75 \%)$ had SIBO, being this the least frequent symptomatical subgroup, as accounted for $18 \%$ of the dyspeptic symptoms. The other types of dyspepsia present were type fullness $(43 \%)$ and type mixed $(39 \%)$. Despite being more prevalent in the population studied, they presented SIBO in a lower percentage on $\mathrm{H}_{2}$ breath test: $50 \%$ and $55.5 \%$, respectively.

Rome III Consensus suggests that the inhibitors of acid secretion (proton pump inhibitors and $\mathrm{H}_{2}$ blockers) are the first choice for patients with functional dyspepsia and predominance of epigastric pain, and the prokinetics (metoclopramide, domperidone, bromopride) for postprandial discomfort ${ }^{(18,23)}$.

In the present study we observed that $12(52.2 \%)$ patients in the dyspeptic group were using PPIs. Of these, $9(75 \%)$ were tested positive for SIBO by $\mathrm{H}_{2}$ breath test. In the same group, $11(47.8 \%)$ did not use PPIs and of these, 5 (45.4\%), showed SIBO quoted in the test. The control group patients did not use PPIs.

Therefore, it was observed a higher prevalence of SIBO in dyspeptic patients that were using PPIs. These results are in agreement with the studies of Lombardo et al. ${ }^{(12)}$, that demonstrate the association between SIBO and the prolonged use of PPIs. However, there was no significant statistical difference when compared with dyspeptic patients without the use of PPIs.

Recent studies demonstrated that gastric acidity and intestinal motility are seen as major mechanisms for the gastrointestinal flora control ${ }^{(26)}$. The use of PPIs reduces the gastric acidity, favoring the appearance of SIBO. The motor disorders, such as the delayed gastric emptying, may lead to the symptoms of dyspepsia and SIBO, since motility is responsible for the scanning of microorganisms that have survived to the stomach $\mathrm{pH}$, inhibiting the bacterial growing in the small intestine ${ }^{(13,19)}$.

This study has some limitations. We found difficulties on finding the control group volunteers, by the fact there only a few healthy patients were willing to be submitted to the breath test. The possibility that dyspeptic patients may have accelerated intestinal transit cannot be discarded, though unlikely.

In conclusion, this study demonstrated a high prevalence of SIBO in patients with functional dyspepsia. Also observed a higher prevalence of SIBO in dyspeptic patients that were using PPIs. Additional studies evaluating the effect of the treatment of SIBO in patients with dyspepsia, may clarify the role played by the intestinal bacterial overgrowth in the genesis of dyspeptic symptoms.

Costa MBG, Azeredo Jr. IL, Marciano RD, Caldeira LM, Bafutto M. Avaliação de supercrescimento bacteriano no intestino delgado em pacientes com dispepsia funcional, utilizando o teste de $\mathrm{H}_{2}$ no ar expirado. Arq Gastroenterol. 2012;49(4):279-83.

RESUMO - Contexto - A dispepsia funcional é uma afeç̧̃o cujos sintomas não estão relacionados à doença de base orgânica; sua etiopatogenia não é bem definida. O supercrescimento bacteriano no intestino delgado (SBID) é caracterizado pelo aumento do número e/ou tipo de bactérias colônicas no trato gastrointestinal superior. A hipótese de SBID associado à dispepsia funcional deve ser considerada, uma vez que o distúrbio de motilidade do trato gastrointestinal é um dos principais fatores etiológicos envolvidos nas duas patologias. Objetivo - Determinar se há presença de SBID em pacientes com dispepsia funcional. Método - Estudo caso-controle, avaliando 34 pacientes: 23 dispépticos funcionais e 11 não dispépticos (grupo controle). Questionário baseado nos critérios de Roma III foi aplicado. Os pacientes se submeteram ao teste de $\mathrm{H}_{2}$ no ar expirado com lactulose, considerado positivo: pico de $\mathrm{H}_{2}$ superior a 20 ppm, em relação ao jejum ou dois picos superiores a 10 ppm sustentados até 60 minutos. Resultados Dos 23 pacientes dispépticos, $13(56.5 \%)$ obtiveram resultado positivo para SBID através do teste de $\mathrm{H}_{2}$ no ar expirado. No grupo controle, não foi evidenciado SBID. A associação entre o grupo dispéptico e o grupo controle em relação ao SBID, mostrou-se estatisticamente significante, com $P=0.0052$. Do grupo dispéptico, $12(52.2 \%)$ pacientes faziam uso de inibidor de bomba de prótons; destes, $9(75 \%)$ apresentaram resultado positivo para SBID. No grupo controle, os 11 pacientes não usavam inibidor de bomba de prótons e não foi evidenciado SBID. Mostrou-se estatisticamente significante a associação do grupo de dispépticos em uso de inibidor de bomba de prótons que tiveram SBID e grupo controle, com $P=0.0011$. Conclusão - Concluiu-se que, pacientes com dispepsia funcional apresentaram SBID, quando submetidos ao teste de $\mathrm{H}_{2}$ no ar expirado, em relação aos não-dispépticos. Além disso, observou-se maior prevalência de SBID em pacientes dispépticos que faziam uso de inibidor de bomba de prótons, em relação ao grupo controle.

DESCRITORES - Crescimento bacteriano. Intestino delgado. Dispepsia. Hidrogênio. Inibidores da bomba de prótons. 


\section{REFERENCES}

1. Abu-Shanabi A, Quera RM, Quigley EMM. Supercrescimento bacteriano no intestino delgado. In: Dani R, Passos MCF, editores. Gastroenterologia essencial. Rio de Janeiro: Guanabara Koogan; 2011. p.402-5.

2. The cost of gastro-esophageal reflux disease, dyspepsia and peptic ulcer disease in Sweden. Pharmacoeconomics. 2002;20:347-55.

3. Brun R, Kuo B. Functional dyspepsia. Ther Adv Gastroenterol. 2010;3:145-64.

4. Bures J, Cyrany J, Kohoutova D, Förstl M, Rejchrt S, Kvetina J, Vorisek V, Kopacova M. Small intestinal bacterial overgrowth syndrome. World J Gastroenterol. 2010;16:2978-90.

5. Chang L. From Rome to Los Angeles - The Rome III Criteria for the Functiona GI Disorders [Internet]. Available from: http://www.medscape.org/viewarticle/533460_print

6. dos Reis JC, de Moraes MB, Fagundes-Neto U. Breath hydrogen test to evaluate lactose absorption and small bowel bacterial overgrowth in children. Arq. Gastroenterol. 1999;36:169-76.

7. Durães ESM, Fabris MR, Faraco AJ, Madeira K, Luca LR. Análise dos achados endoscópicos em pacientes com dispepsia atendidos no serviço de endoscopia do Hospital São João Batista, Criciúma, SC, no período de outubro de 2008 a março de 2009. GED Gastroenterol Endosc Dig. 2010;29:73-8.

8. Filer SN, Rose S. Is functional dyspepsia of particular concern in women? A review of gender differences in epidemiology, pathophysiologic mechanism, clinical presentation, and management. Am J Gastroenterol. 2006;101:s644-s53.

9. Haddad MTB. Doenças funcionais gastrointestinais. In: Chinzon D, Marinho JR, Ramos Jr. O, editores. Gastroenterologia: ciência e tecnologia aplicadas à prática clínica. São Paulo: Federação Brasileira de Gastroenterologia; 2010. p.189-92.

10. Karamanolis G, Caenepeel P, Arts J, Tack J. Association of the predominan symptom with clinical characteristics and pathophysiological mechanisms in functional dyspepsia. Gastroenterology. 2006;130:296-303.

11. Lin HC. Does small intestinal bacterial overgrowth contribute to functional dyspepsia [Internet] [Cited 2012 Mar 13]. New Mexico: VA Healthcare System. Available from: <http://clinicaltrials.gov/ct2/show/NCT00956397>.

12. Lombardo L, Foti M, Ruggia O, Chiecchio A. Increased incidence of small intestinal bacterial overgrowth during proton pump inhibitor therapy. Clin Gastroenterol Hepatol. 2010;8:504-8.

13. Longstreth GF. Functional dyspepsia - managing conundrum. N Engl J Med 2006;354:791-3.
14. Madrid AM, Defilippi CC, Slimming AJ, Quera PR. Small intestinal bacterial overgrowth in patients with functional gastrointestinal diseases. Rev Med Chil. 2007; $135: 1245-52$

15. Montalto M, Curigliano V, Santoro L, Vastola M, Cammarota G, Manna R, Gasbarrini A, Gasbarrini G. Management and treatment of lactose malabsorption. World J Gastroenterol. 2006:12:187-91.

16. Pajares García JM. Functional dyspepsia and Helicobacter pylori - A stable coexistence? Rev Esp Enferm Dig. 2008;100:525-31.

17. Quera PR, Quigley EM, Madrid AM. Small intestinal bacterial overgrowth. An update. Rev Med Chile. 2005;133:1361-70.

18. Ramos AFP, Passos MCF. Dispepsia funcional. In: Dani R, Passos MCF, editores Gastroenterologia essencial. Rio de Janeiro: Guanabara Koogan; 2011. p.165-71.

19. Salgado CJ, Resende CC, Ferrari MLA. Intolerância à lactose e supercrescimento bacteriano intestinal. In: Savassi-Rocha PR, Coelho LGV, Moretzshn LD, Passos MCF, editores. Tópicos em Gastroenterologia 16: Afecções menos freqüentes em Gastroenterologia. Rio de Janeiro: Medbook; 2007. p.203-17.

20. Silva FM. Dispepsia: caracterização e abordagem. Rev Med. 2008;87:213-23.

21. Stotzer PO, Johansson C, Mellström D, Lindstedt G, Kilander AF. Bone mineral density in patients with small intestinal bacterial overgrowth. Hepatogastroenterology. 2003;50:1415-8.

22. J Functional gastroduodenal disorders. Gastroenterology. 2006:130:1466-79.

23. Tack J, Masaoka T, Janssen P. Functional dyspepsia. Curr Opin Gastroenterol. 2011;27:549-57.

24. Teo M, Chung S, Chitti L, Tran C, Kritas S, Butler R, Cummins A. Small bowel bacterial overgrowth is a common cause of chronic diarrhea. J Gastroenterol Hepatol. 2004;19:904-9.

25. Vanderhoof JA, Pauley-Hunter RJ. Clinical manifestations and diagnosis of small intestinal bacterial overgrowth [Internet]. Available from: http://www.uptodate. $\mathrm{com} /$ contents/clinical-manifestations-and-diagnosis-of-small-intestinal-bacterial-overgrowth?source $=$ search_result\&search $=$ sibo\&selectedTitle $=2 \% 7 \mathrm{E} 111^{*}$

26. Vanderhoof JA, Pauley-Hunter RJ. Etiology and pathogenesis of small intestinal bacterial overgrowth [Internet]. Available from: http://www.uptodate.com/ contents/etiology-and-pathogenesis-of-small-intestinal-bacterial-overgrowth?source $=$ see_link

Received 22/6/2012 Accepted 16/8/2012 